\title{
Relation Of Knowledge About Diabetes Mellitus With Motivation To Prevent Complications In Pematang Reba The Working Area Of Pekan Heran`s Public Healpth Center Of Indragiri Hulu Regency
}

\author{
Alice Rosy \\ Poltekkes Kemenkes Riau \\ alicerosyamk@gmail.com
}

\section{Article Info}

\section{Article history}

Received date: 2019-12-06

Revised date: 2020-07-10

Accepted date: 2020-07-24

\begin{abstract}
Different levels of knowledge of diabetics will cause different motivations in preventing complications in people with diabetes mellitus. Most sufferers are in the Public Health Center of Pekan Heran, which is 330 patients. The purpose of this study was to determine the relationship of knowledge about Diabetes Mellitus with motivation in preventing complications in the Kelurahan Pematang Reba, Public Health Center Pekan Heran, Indragiri Hulu District. The research method is descriptive correlative with cross sectional approach, the sampling technique is total sampling, 70 respondents, by distributing questionnaires. Analysis of the data in this study is univariate and bivariate analysis. The results showed that the majority of sufferers' knowledge about diabetes mellitus was good $(90 \%)$, most patients had strong motivation in preventing complications of diabetes mellitus (94.3\%). There is a relationship between knowledge about Diabetes Mellitus with motivation in preventing complications with a $p$ value of 0.02 or $<0.05$.
\end{abstract}

\section{Keywords:}

Knowledge, Diebetes Mellitus, Motivation, Complications

\begin{abstract}
Abstrak
Tingkat pengetahuan penderita diabetes yang berbeda-beda akan menimbulkan motivasi yang berbeda-beda pula dalam mencegah terjadinya komplikasi pada penderita diabetes mellitus. Penderita terbanyak berada di wilayah kerja Puskesmas Pekan Heran yaitu 330 penderita. Tujuan penelitian adalah untuk mengetahui hubungan pengetahuan tentang Diabetes Mellitus dengan motivasi dalam mencegah teriadinya komplikasi di Kelurahan Pematang Reba Wilayah Keria Puskesmas Pekan Heran Kabupaten Indragiri Hulu. Metode penelitian adalah deskriptif korelatif dengan pendekatan cross sectional, teknik pengambilan sampel adalah total sampling, responden sebanyak 70 orang, dengan menyebarkan kuisioner. Analisa data pada penelitian yaitu analisa univariat dan bivariat. Hasil penelitian menunjukan sebagian besar pengetahuan penderita tentang diabetes mellitus baik (90\%), sebagian besar pasien memiliki motivasi yang kuat dalam mencegah teriadinya komplikasi diabetes mellitus (94,3\%). Terdapat hubungan antara pengetahuan tentang Diabetes Mellitus dengan motivasi dalam mencegah terjadinya komplikasi dengan $p$ value 0,02 atau $<0,05$.
\end{abstract}

Kata Kunci

Pengetahuan, Diebetes Mellitus, Motivasi, Komplikasi 


\section{PENDAHULUAN}

Diabetes mellitus merupakan penyakit yang memiliki komplikasi atau menyebabkan terjadinya penyakit lain yang paling banyak. Hiperglikemia atau tingginya kadar glukosa dalam darah yang terjadi dari waktu ke waktu dapat menyebabkan kerusakan berbagai sistem tubuh terutama pada syaraf dan pembuluh darah. Komplikasi DM yang sering terjadi antara lain : gagal ginjal, retinopati diabeticum, neuropati diabeticum, neuropati (kerusakan syaraf) dikaki yang meningkatkan kejadian ulkus kaki, infeksi dan bahkan keharusan untuk amputasi kaki. Meningkatnya resiko penyakit jantung, stroke dan resiko kemtian penderita diabetes secara umum adalah dua kali lipat dibandingkan bukan penderita DM[1].

Meningkatnya kadar gula darah secara perlahan-lahan bisa berpotensial merusak pembuluh darah, saraf dan struktur internaknya. Kadar gula darah yang tidak terkontrol juga cenderung menyebabkan kadar zat lemak dalam darah meningkat, sehingga mempercepat terjadinya arteriosclerosis (penebalan dan hilangnya elastic dinding arteri), yang mengakibatkan gangguan sirkulasi pada pembuluh darah besar dan kecil, bisa melukai jantung, otak, tungkai, mata, ginjal, saraf, kulit, serta memperlambat penyembuhan luka karena berkurangnya aliran darah ke kulit.

Jumlah penderita diabetes mellitus di dunia mencapai 422 juta orang atau $8.9 \%$ penduduk dunia. $90 \%$ merupakan penderita DM tipe 2 dan 10\% DM tipe 1. Pada tahun 2013 jumlah penderita diabetes mellitus di
Indonesia telah mencapai angka 14 juta orang, dimana baru $50 \%$ yang sadar mengidapnya dan diantara mereka baru sekitar $30 \%$ yang datang berobat teratur[4].

Selain itu, menurut laporan dari beberapa tempat di Indonesia, angka kejadian dan komplikasi DM cukup tersebar sehingga bisa dikatakan sebagai salah satu masalah nasioanl yang harus mendapat perhatian lebih[3].

Berdasarkan data dari International Diabetes Federation (IDF) 2017, penderita diabetes didunia mencapai 424,9 juta jiwa yang diperkirakan akan terus bertambah dan mencapai 628,6 juta jiwa pada tahun 2045. Berdasarkan International Diabetes Federation 2017, Indonesia termasuk kedalam kelompok western pacific dengan penderita diabetes sebanyak 158,8 juta jiwa artinya $37,4 \%$ dari populasi tersebut merupakan penderita diabetes dan 1,3 juta jiwa diantaranya meninggal karena diabetes. Indonesia menempati peringkat ke 6 negara dengan penderita diabetes terbanyak, yakni 10,3 juta jiwa dan diperkirakan akan terus bertambah menjadi 16,7 juta jiwa pada tahun 2045. Secara keseluruhan, diperkirakan masih ada $84,5 \%$ disemua kasus yang tidak terdiagnosa yang berasal dari Negara berkembang. Di Indonesia diperkirakan terdapat 7,6 juta jiwa yang belum terdiagnosa diabetes mellitus.

Tahun 2015 pola penyakit rawat jalan di rumah sakit Provinsi Riau jumlah penderita diabetes mellitus type 1 sebanyak 13.668 kasus, jumlah penderita diabetes mellitus 
type 2 beserta komplikasi sebanyak 12.315 kasus (Dinas Kesehatan Provinsi Riau, 2015). Berdasarkan data dari Kabupaten Indragiri Hulu penderita diabetes mellitus dalam 3 tahun terakhir di Irna Interna pada tahun 2014 jumlah penderita diabetes mellitus 54 kasus, sedangkan pada tahun 2015 bejumlah 76 kasus dan pada tahun 2016 mengalami penurunan menjadi 75 kasus[5]. Modalitas utama dalam penatalaksanaan diabetes mellitus terdiri dari terapi non farmakologis yang meliputi perubahan gaya hidup dengan melakukan pengaturan pola makan yang dikenal sebagai terapi gizi medis, meningkatkan aktivitas jasmani, dan edukasi berbagai masalah yang berkaitan dengan penyakit diabetes mellitus yang dilakukan secara terus menerus, dan terapi famalokogis seperti terapi insulin untuk menjaga kadar gula darah normal atau mendekati normal [4].

Pengetahuan atau kognitif merupakan domain yang sangat penting untuk terbentuknya tindakan atau perilaku seseorang [6]. Perilaku yang didasari oleh pengetahuan dan sikap posistif, akan berlangsung langgeng. Pengetahuan penderita mengenai diabetes mellitus merupakan saran yang membantu penderita menjalankan penanganan diabetes selama hidupnya. Dengan demikian semakin banyak dan semakin baik penderita mengerti mengenai penyakitnya, maka semakin mengerti bagaimana harus mengubah perilakunya dan mengapa hal itu diperlukan [3].

Motivasi dapat diartikan sebagai kecendrungan atau keinginan yang tinggi terhadap sesuatu [7]. Dengan motivasi yang kuat dari diri sendiri maupun orang lain makan semakin kuat keinginan penderita mengubah perilakunya dalam melaksanakan pencegahan terhadap terjadinya komplikasi. Kurangnya pengetahuan penderita mengenai pengaturan makan atau diet yang benar yakni sesuai umur, berat badan serta jumlah energi yang harus dikeluarkan perhari, akan mengakibatkan tidak terkontrolnya kadar gula darah dalam tubuh pasien, serta tidak terkendalinya proses perkembangan penyakit, termasuk munculnya komplikasi diabetes mellitus.

\section{METODE}

Penelitian ini merupakan penelitian deskriptif koleratif dengan pendekatan Cross Sectional yaitu suatu penelitian untuk mempelajari variabel sebab atau resiko dan akibat atau kasus yang terjadi pada objek penelitian dengan cara pengumpulan data sekaligus pada suatu saat terhadap penderita tentang "Hubungan Pengetahuan Tentang Diabetes Mellitus Dengan Motivasi Dalam Mencegah Terjadinya Kompikasi Di Desa Pematang Reba Wilayah Kerja Puskesmas Pekan Heran Kabupaten Indragiri Hulu Tahun 2017".

Sampel adalah objek yang diteliti dan dianggap mewakili seluruh populasi [6]. Adapun yang menjadi sampel dalam penelitian ini adalah semua penderita diabetes mellitus yang berada di Kelurahan Pematang Reba Wilayah Kerja Puskesmas Pekan Heran yang berjumlah 70 orang, dalam penelitian ini pengambilan sampel berdasarkan metode sampling jenuh.

\section{HASIL DAN PEMBAHASAN}

Hasil yang didapatkan yaitu sebagian besar pengetahuan penderita diabetes adalah baik tentangdiabetes yaitu sebanyak 63 responden (90\%). Hasil uji statistic Chisquare menunjukan bahwa terdapat hubungan antara pengetahuan tentang diabetes mellitus dengan motivasi dalam mencegah terjadinya kompikasi di Desa Pematang Reba Wilayah Kerja Puskesmas 
Pekan Heran Kabupaten Indragiri Hulu Tahun 2017

\section{Analisa Univariat}

Tabel. 1

Distribusi Frekuensi Pengetahuan Tentang Diabetes Mellitus di Kelurahan Pematang Reba Wilayah Kerja

Puskesmas Pekan Heran Kabupaten Indragiri Hulu Tahun 2017

\begin{tabular}{|c|c|c|c|}
\hline No & Kriteria & Frekuensi & Persentase( $\%)$ \\
\hline 1 & Baik & 63 & 90 \\
\hline 2 & Cukup & 7 & 10 \\
\hline \multirow[t]{2}{*}{3} & Kurang & 0 & 0 \\
\hline & Total & 70 & 100 \\
\hline \multicolumn{3}{|c|}{ pengetahuan yang baik tentang Diabetes } & $\begin{array}{l}\text { en memiliki } \\
\text { ang Diabetes }\end{array}$ \\
\hline \multicolumn{4}{|c|}{ Melitus yaitu sebayak 63 orang (90\%). } \\
\hline
\end{tabular}

Tabel. 2

Distribusi Frekuensi Motivasi Dalam Mencegah Terjadinya Komplikasi di Kelurahan Pematang Reba Wilayah Kerja Puskesmas Pekan Heran Kabupaten Indragiri Hulu Tahun 2017

\begin{tabular}{llcc}
\hline No & Kriteria & Frekuensi & Persentase (\%) \\
\hline 1 & Kuat & 66 & 94,3 \\
2 & Sedang & 4 & 5,7 \\
3 & Lemah & 0 & 0 \\
\hline & Total & 70 & 100 \\
\hline
\end{tabular}

Berdasarkan tabel diatas menunjukan bahwa sebagian besar responden yaitu 66 orang $(94,3 \%)$ memiliki motivasi yang kuat dalam mencegah terjadinya kompikasi Diabetes Melitus Di Desa Pematang Reba Wilayah Kerja Puskesmas Pekan Heran Kabupaten Indragiri Hulu Tahun 2017.

\section{Analisa Bivariat}

Tabel. 3

Hubungan Pengetahuan Tentang Diabetes Mellitus Dengan Motivasi Dalam Mencegah Terjadinya Komplikasi di Kelurahan Pematang Reba Wilayah Keria Puskesmas Pekan Heran Kabupaten Indragiri Hulu Tahun 2017

\begin{tabular}{|c|c|c|c|c|c|c|c|c|c|}
\hline \multirow{4}{*}{$\begin{array}{l}\text { Peng } \\
\text { etahu } \\
\text { an }\end{array}$} & \multirow{2}{*}{\multicolumn{6}{|c|}{$\begin{array}{c}\text { Motivasi Dalam Mencegah } \\
\text { Terjadinya Komplikasi }\end{array}$}} & \multirow{2}{*}{\multicolumn{2}{|c|}{ Total }} & \multirow{3}{*}{$\begin{array}{c}p \\
\text { val }\end{array}$} \\
\hline & & & & & & & & & \\
\hline & \multicolumn{2}{|c|}{ Lemah } & \multicolumn{2}{|c|}{ Sedang } & \multicolumn{2}{|c|}{ Kuat } & \multirow[b]{2}{*}{$f$} & \multirow[b]{2}{*}{$\%$} & \\
\hline & $\mathbf{F}$ & $\%$ & $f$ & $\%$ & $\mathbf{F}$ & $\%$ & & & \\
\hline Baik & 0 & 0 & 0 & 0 & 0 & 0 & 63 & 90 & \\
\hline Cukup & 0 & 0 & 3 & 42,9 & 4 & 57,1 & 7 & 10 & \\
\hline Kuran & 0 & 0 & 1 & 1,6 & 62 & 98,4 & 0 & 0 & 0,0 \\
\hline $\mathrm{g}$ & & & & & & & & & 2 \\
\hline \multirow[t]{2}{*}{ Total } & 0 & 0 & 4 & 5,7 & 66 & 94,3 & 70 & 10 & \\
\hline & & & & & & & & 0 & \\
\hline
\end{tabular}

Berdasarkan tabulasi silang antara pengetahuan tentang Diabetes Mellitus dengan motivasi dalam mencegah terjadinya komplikasi di Kelurahan Pematang Reba Wilayah Kerja Puskesmas Pekan Heran Kabupaten Indragiri Hulu menunjukkan bahwa dari 70 penderita Diabetes Mellitus sebanyak 63 penderita Diabetes Mellitus (90\%) yang memiliki pengetahuan baik, memiliki motivasi sedang 1 penderita $(1,6 \%)$ dan yang memiliki pengetahuan baik, memiliki motivasi kuat 62 penderita $(98,4 \%)$.

Berdasarkan hasil uji statistic Chi Square didapatkan hasil ada hubungan yang bermakna dengan nilai $p$ value 0,02 atau $<$ 0,05, dapat disimpulkan bahwa Ho ditolak, artinya terdapat hubungan antara pengetahuan tentang diabetes mellitus dengan motivasi dalam mencegah terjadinya komplikasi di Kelurahan Pematang Reba Wilayah Kerja Puskesmas Pekan Heran Kabupaten Indragiri Hulu. 


\section{Analisa Univariat}

Berdasarkan hasil penelitian yang dilakukan di Kelurahan Pematang Reba Wilayah Kerja Puskesmas Pekan Heran Kabupaten Indragiri Hulu pada 70 orang penderita Diabetes Mellitus pengetahuan tentang Diabetes Mellitus Mayoritas berpengetahuan baik yaitu sebanyak 63 orang $(90 \%)$ ini dapat dilihat dari kemampuan responden menjawab benar untuk pertanyaan tentang pengertian Diabetes Mellitus (83\%), tanda dan gejala $(87 \%)$, komplikasi $(47 \%)$, dan pencegahan (84\%). Pengetahuan merupakan hasil tahu, yang terjadi setelah orang melakukan pengindraan terhadap objek tertentu. Sebagian besar pengetahuan diperoleh melalui mata dan telinga. Pengetahuan merupakan pedoman dalam membentuk tindakan seseorang (overt behavior). Berdasarkan pengalaman dan penelitian, diperoleh bahwa perilaku yang didasari oleh pengetahuan lebih langgeng dari pada perilaku yang tidak didasari pengetahuan [10].

Motivasi penderita Diabetes Mellitus dalam melakukan pencegahan komplikasi di Kelurahan Pematang Reba Wilayah Kerja Puskesmas Pekan Heran Kabupaten Indragiri Hulu mayoritas memiliki motivasi kuat yaitu sebanyak 66 orang $(94,3 \%)$ ini dapat dilihat dari responden yang menjawab pernyataan positif tentang mencari informasi tentang cara mencegah terjadinya komplikasi Diabetes Mellitus yang menyatakan sangat setuju 43 responden $(61 \%)$, setuju 26 responden $(37 \%)$. Pernyataan positif keinginan yang kuat untuk memeriksakan (cek) kadar gula darah yang menyatakan sangat setuju 45 responden $(64 \%)$, setuju 25 responden (36\%). Pernyataan tentang semangat berolahraga karena ada orang terdekat atau keluarga yang menemani yang menyatakan sangan setuju 39 responden $(56 \%)$, setuju 31 responden $(44 \%)$.
Motivasi merupakan suatu dorongan pada seseorang untuk bertindak, mendorong seseorang mencapai tujuan tertentu dan membuat seseorang tertarik dalam melakukan kegiatan tertentu. Motivasi ini dibagi menjadi dua yaitu motivasi dari dalam diri individual sendiri (intrinsik) maupun dari dorongan luar individu (ekstrinsik). Motivasi yang terbaik terutama adalah motivasi intrinsik karena motivasinya untuk melakukan sesuatu datang dari dalam dirinya sendiri [8]. Secara individual motivasi seseorang sangatlah personal. Satu dengan yang lainnya berbeda. Mereka mendapatkan dan mendasarkan atas nilainilai tertentu sesuai dengan pandangan dan dasar hidupnya [9]. Meskipun demikian secara mendasar atau hakiki, tujuan motivasi adalah untuk mendapatkan sesuatu atau terhindar dari sesuatu, dapat disimpulkan dari hasil penelitian dengan motivasi yang kuat penderita diabetes mellitus dalam mencegah terjadinya komplikasi dapat menghindari diri dari komplikasi yang akan terjadi.

Jika seseorang mendapatkan motivasi yang tepat, maka lepaslah tenaga yang luar biasa, sehingga tercapai hasil-hasil yang semula tidak terduga [11]. Motivasi adalah kebutuhan psikologi yang telah memiliki corak atau arah yang ada dalam diri individu yang harus dipenuhi agar kehidupan kejiwaannya terpelihara yaitu senantiasa dalam keadaan seimbang. Pada awalnya kebutuhan itu hanya berupa kekuatan dasar saja. Namun, selanjutnya berubah menjadi suatu vector yang disebut motivasi karena memiliki kekuatan dan arah [12].

\section{Analisa Bivariat}

Berdasarkan hasil uji statistic Chi Square pada tabel 4.3 dapat disimpulkan bahwa $p$ value 0,02 atau $<0,05$ menunjukkan ada hubungan antara pengetahuan tentang diabetes mellitus dengan motivasi dalam 
mencegah terjadinya komplikasi di Kelurahan Pematang Reba Wilayah Kerja Puskesmas Pekan Heran Kabupaten Indragiri Hulu.

Pengetahuan (knowledge) merupakan hasil rasa keingintahuan manusia terhadap sesuatu dan hasrat untuk meningkatkan harkat hidup sehingga kehidupan menjadi lebih baik dan nyaman yang berkembang sebagai upaya untuk memenuhi kebutuhan manusia baik dimasa sekarang maupun dimasa depan [13].

Penelitian yang dilakukan saat ini selaras dengan penelitian yang dilakukan oleh Meydani (2011), tentang Faktor - Faktor yang Berhubungan Dengan Upaya Pencegahan Komplikasi DM Oleh Pasien DM di Poliklinik Khusus Penyakit Dalam RSUP DR M. Djamil Padang, yang menyebutkan bahwa ada hubungan yang bermakna antara motivasi dengan upaya pencegahan komplikasi DM dengan $p$ value $<0,05$, dan hasil penelitian ini juga sejalan dengan penelitian yang dilakukan oleh Mulya (2014), dengan judul Hubungan Pengetahuan dan Motivasi Penderita Diabetes Mellitus Dengan Upaya Pencegahan Ulkus Diabetikum Di Poli Penyakit Dalam Rumah Sakit Achmad Mochtar Bukit Tinggi dengan hasil ada hubungan yang signifikan antara pengetahuan dengan pencegahan Ulkus Diabetikum $(p=0,000)$ dan $(r=23,111)$ dan terdapat hubungan yang signifikan antara motivasi dengan pencegahan ulkus $(p=0,00)$ dan $(r=37,917)$.

Hasil penelitian ini terdapat hubungan yang signifikan antara pengetahuan tentang Diabetes Mellitus dengan Motivasi dalam mencegah terjadinya komplikasi $(p=0,02)$. Semakin baik pengetahuan penderita Diabetes Mellitus maka semakin baik juga motivasi penderita Diabetes Mellitus dalam mencegah terjadinya komplikasi, dengan nilai $(O R=46,500)$ dapat meningkatkan 46 kali motivasi dalam mencegah terjadinya komplikasi. Salah satu faktor intrinsik yang mempengaruhi pengetahuan adalah motivasi. Motivasi akan dilaksanakan dengan baik apabila seseorang mengetahui manfaat yang bisa diambil sehingga dibutuhkan pengetahuan yang memadai tentang hal tersebut. Pengetahuan yang rendah dapat mempengaruhi persepsi pasien tentang penyakit diabetes mellitus 12 Motivasi dapat diartikan sebagai kecendrungan atau keinginan yang tinggi terhadap sesuatu. Motivasi merupakan kekuatan dari dalam dan dampak dari luar sebagai gerak-gerik dalam menjalankan.

\section{SIMPULAN}

1. Pengetahuan penderita Diabetes Mellitus di Kelurahan Pematang Reba Wilayah Keria Puskesmas Pekan Heran Kabupaten Indragiri Hulu dari 70 penderita, 63 (90\%) penderita Diabetes Mellitus yang berpengetahuan baik, 7 (10\%) penderita Diabetes Mellitus yang berpengetahuan cukup.

2. Motivasi penderita Diabetes Mellitus di Kelurahan Pematang Reba Wilayah Kerja Puskesmas Pekan Heran Kabupaten Indragiri Hulu dari 70 penderita, 66 (94,3\%) penderita Diabetes Mellitus yang mempunyai motivasi kuat, 4 (5,7\%) penderita Diabetes Mellitus yang mempunyai motivasi sedang.

3. Berdasarkan analisa bivariat didapatkan bahwa ada hubungan antara pengetahuan tentang Diabetes Mellitus dengan motivasi dalam mencegah terjadinya komplikasi di Kelurahan Pematang Reba Wilayah Kerja Puskesmas Pekan Heran Kabupaten Indragiri Hulu dibuktikan dengan uji statistic Chi Square $p$ Value 0,02 atau $<0,05$. 


\section{UCAPAN TERIMA KASIH}

Saya mengucapkan terimakasih kepada pihak Puskesmas Pekan heran dan penderita Diabetes Melitus atas kerjasamanya pada penelitian ini.

\section{DAFTAR PUSTAKA}

[1] Kemenkes RI. (2015). Profil Kesehatan Indonesia tahun 2014. Jakarta : Kemenkes RI.

[2] WHO. (2015). Diabetes Mellitus. Diakses pada tanggal 27 September 2017. Diperoleh dari http://www.who.int/mediacentre/news /releases/2016/world-healthday/en/

[3] Waspadii, S. (2007). Penatalaksanaan DM terpadu. Jakarta: Fakultas Kedokteran Universitas Indonesia.

[4] Rekam Medik RSUD Indrasari Rengat. (2017). Rakapitulasi Penderita Diebetes Mellitus Beserta Komplikasinya Di RSUD Indrasari Rengat.

[5] Notoadmodjo, S. (2012) Metodologi Penelitian Kesehatan. Jakarta: Rineka Cipta.

[6] M. Chazienul Ulum. (2016) Perilaku Organisasi Menuju Orientasi Pemebrdayaan. UB Press.

[7] Sunaryo. (2014). Psikologi Untuk Keperawatan._Jakarta: EGC.

[8] Donsu, J.D.T (2017). Psikologi Keperawatan. Yogyakarta:Pustaka Baru Press

[9] Asriwati. (2019). Buku ajar antropologi dalam keperawatan. Deeppublish

[10] Purwanto, M. N. (2006). Psikologi Pendidikan._ Bandung: Remaja Rosda Karya.
[11] Zuyina L, dan Bandiah, S. (2008). Psikologi Kesehatan. Yogyakarta: Mitra Cendika.

[12] Susan. (2011) Self care science nursing theory and evidence based. Springer Publishing Company

[13] Wawan dan Dewi. (2010) Teori dan pengukuran pengetahuan sikap dan perilaku manusia.

[14] Meydani. (2016). Faktor-Faktor Yang Berhubungan Dengan Upaya Pencegahan Komplikasi Dm Oleh Pasien Dm Di Poliklinik Khusus Penyakit Dalam Rsup Dr M.Diamil Padang 